\title{
ADOPSI SISTEM E-COMMERCE \\ SEBAGAI MODEL LAYANAN PENGUNJUNG DESA WISATA DI KABUPATEN BONDOWOSO
}

\author{
I Ketut Mastika \\ Prodi Ilmu Administrasi Bisnis, FISIP Universitas Jember \\ Email: i.ketut.mastika@gmail.com \\ Sasongko \\ Prodi Ilmu Administrasi Bisnis, FISIP Universitas Jember \\ Email: saspasca@yahoo.co.id \\ Rudy Eko Pramono \\ Prodi Ilmu Administrasi Bisnis, FISIP Universitas Jember \\ Email: rudyekopramono1@gmail.com \\ Didik Eko Julianto \\ Prodi Ilmu Administrasi Bisnis, FISIP Universitas Jember \\ Email: didikjulianto@yahoo.com

\section{Sri Wahyuni} \\ Prodi Ilmu Administrasi Bisnis, FISIP Universitas Jember \\ Email: yuni.adbispar@gmail.com
}

\begin{abstract}
This paper examines the adoption of e-commerce system models in the rural tourism sector. Rural tourism business infrastructure barriers be resolved with application ride sharing system named 'Terater' and e-payment with the name 'Ebajer'. Research using qualitative methods to explore information from the subject of the research. The existence of a model system for Ride Sharing such Go-jek in 50 cities in Indonesia, able to inspire the TERATER initiator, community, adopt ecommerce system as a model of service to visitors. The utilization of e-commerce helps a lot and makes it easy for rural home industry to market and Transaction. In the E-Commerce systems can guarantee the existence of real data and real money. The results of the research can be used to initiate the expansion of the adoption of ecommerce systems in the development of regional tourism its main tourist village.
\end{abstract}

Keywords: E-Commerce, Tourism Village, Gojek 


\section{Pendahuluan}

E-commerce (electronic commerce) sebagai bentuk fenomena metode baru yang menyediakan infrastruktur bisnis modern melalui internet. E-commerce memungkinkan interaksi pasar (produsen dan konsumen) yang tidak berkumpul di satu tempat, bisa bertransaksi secara cepat dan mudah. Calon pembeli dapat mengetahui info mengenai produk seperti jenis produk, harga, tempat, dan sebagainya. Media "periklanan" menjadi sangat penting bagi pengelola desa wisata dalam mengomunikasikan pemasaran bisnis kuliner desa, objek dan atraksi wisata desa, tarif dan biaya, antar jemput melalui layanan transportasi online. Sehingga tujuan penggunaan dan pemanfaatan media internet untuk dapat membantu dan memudahkan (efisien dan efektif) dalam memberikan pengenalan produk dan layanan wisata desa bagi masyarakat luas agar berminat memanfaatkan kemudahan tersebut dengan tidak memandang ruang dan waktu. Strategi pemasaran ini merupakan langkah cemerlang dalam berinovasi dalam upaya pengembangan desa wisata sebagai terobosan ke jenjang pola bisnis modern.

Tidak dipungkiri bahwa dunia persaingan yang berjalan sangat ketat, juga terjadi dalam dunia pariwisata termasuk desa wisata. Akan sangat memprihatinkan ketika destinasi desa wisata mulai dikembangkan dengan pola meniru dari desa wisata satu ke desa wisata lain, lebih-lebih tanpa mempertimbangkan aspek diferensiasi antar kawasan, maka akan menimbulkan kelesuan dan menurunkan semangat masyarakat lokal untuk berpartisipasi. Oleh karena itu, tantangan bagi pemerintah daerah sebagai pengambil kebijakan dalam pembangunan desa wisata, sangat penting mengajak para penggiat pariwisata, innovator, programmer yang memiliki visi dan kapasitas pemanfaatan sistem teknologi virtual. Hal tersebut untuk memperkuat bisnis masyarakat lokal di kawasan desa wisata dengan mempergunakan media-media periklanan dalam memasarkan produk dan layanan wisata desa. Gagasan pemanfaatan internet ini akan memperkuat daya penetrasi 
media periklanan yang biasanya menggunakan media cetak dan media elektronik konvensional.

Pemanfaatan internet dan media pendukung seperti komputer maupun mobile communications melahirkan berbagai bentuk bisnis berbasis elektronik (ecommerce) atau juga dikenal transksi online dan sebagainya. Terwujudnya kolaborasi dan adopsi e-commerce tentu saja membutuhkan pelibatan dan peran serta masyarakat lokal secara aktif dan partisipatif. Pemberdayaan komunitas lokal di kawasan pengembangan pariwisata tidak saja bertujuan memberi peluang ekonomis, akan tetapi secara sinergis kehadiran masyarakat sebagai pelaku pariwisata dapat menambah daya tarik wisata yang ada. Pemberdayaan masyarakat melalui pariwisata berarti proses membangun dan mengembalikan kepercayaan diri masyarakat, bahwa mereka mampu membangun potensi pariwisata yang dimiliki (Muntu, A.W., et al., 2017). Peran partisipasi masyarakat akan semakin fokus apabila bergerak sebagai komunitas, sepertinya komunitas yang memanfaatkan kecanggihan teknologi dalam memfasilitasi aktivitas dan transaksi bisnis pariwisata semakin menyeruak. Di beberapa destinasi pariwisata yang dikelola oleh komunitas, wisatawan menginap di rumah-rumah penduduk, belajar membatik, menari dan lebih intens menyelami living culture masyarakat setempat (Pakpahan, 2018). Masalah adopsi e-commerce dalam pengembangan desa wisata di kabupaten Bondowoso menjadi fokus menarik dalam kajian ini. Pertanyaan yang ingin diperoleh jawaban adalah, "Bagaimana adopsi dan aplikasi teknologi pemanfaatan sistem e-commerce dalam pengembangan desa wisata di kabupaten Bondowoso.

\section{Program Universal Service Obligation (USO)}

Pemerintah telah merealisasikan komitmen menyiapkan pelayanan sistem telekomunikasi secara adil dan merata melalui beberapa program seperti; penyediaan desa pintar, program internet sehat serta aman, pusat layanan internet kecamatan, mobil pusat layanan internet kecamatan, pengadaan internet exchange, program penyelenggaraan jasa internet, sebagai perwujudan kebijakan program 
USO (universal service obligation). Semua bentuk program yang telah diluncurkan pemerintah dimaksudkan sebagai penyediaan infrastruktur dibidang ICT kepada lapisan masyarakat di pedesaan. Pengembangan infrastruktur teknologi komunikasi tersebut di arahkan untuk mencapai sasaran peningkatan produktivitas perekonomian di daerah. Eksistensi pengembangan teknologi informasi dan komunikasi tersebut merupakan bentuk pemberdayaan bagi individu (individual empowering) dan dapat meningkatkan kadar konektivitas sosial maupun keterlibatan masyarakat sipil (D’Allensandro \& Dosa,2001; Katz, et al, 2001).

Pemerintah menyadari pentingnya mendorong proses menuju terwujudnya masyarakat modern yang mampu beradaptasi dengan lingkungan globalisasi. Pemerintah merealisasi tujuan itu melalui kebijakan yang mampu meningkatkan kualitas kehidupan masyarakat di wilayah pedesaan bahkan ke pelosok desa melalui penyediaan infrastruktur jaringan internet. Pengembangan program internet masuk desa juga memiliki kondisi yang dikenal dengan istilah "digital divide", yaitu suatu kondisi dimana ketersediaan sarana informasi dan komunikasi seperti; komputer, internet networking, layanan komunikasi telepon yang cepat dan murah, mampu menjangkau kawasan lapisan masyarakat yang lebih luas, sering tidak bisa diakses secara lebih merata. Kondisi itu tentu sangat berbeda dengan keberadaan fasilitas ICT yang ada di wilayah perkotaan. Kondisi mereka jauh lebih baik dalam menikmati layanan ICT, sementara masyarakat di pedalaman masih terkendala untuk memiliki komputer yang lebih baik, kualitas jaringan internet dan telepon yang lebih baik dan cepat. Selwyn (2004) mengemukakan bahwa konsep digital divide yang merebak sebagai wacana paska adopsi (post adoption issues), diantaranya terkait dengan tingkat aksesibilitas individu terhadap teknologi, peran aktual dalam pemanfaatan internet serta sasaran hasil jangka pendek maupun segala konsekuensi keberlanjutan penggunaan fasilitas teknologi.

Negara-negara berkembang sangat berkepentingan mengadopsi konsep digital divide guna memperhatikan kesenjangan pembangunan daerah perkotaan (urban) dibandingkan daerah pedalaman atau pelosok desa (remote area). Hal 299 JUMPA Volume 05, Nomor 02, Januari 2019 
tersebut tentu sangat mendasar mengingat kesenjangan dalam pemanfaatan fasilitas infrastruktur ICT di perkontaan lebih dirasakan manfaatnya oleh masyarakat urban. Mereka lebih mudah mendapatkan akses pemanfaatan ICT, mampu mengikuti perkembangan teknologi komputer terbaru (the latest edition). Sementara upaya pendorong kualitas layanan ICT pedesaan perlu terus ditingkatkan mengingat kemanfaatannya sangat besar, sebagaimana hasil kajian dari pihak UNAIR, ITB, dan ITS yang mengindikasikan bahwa penyediaan sarana prasarana ICT pedesaan sangat dibutuhkan, selain sebagai infrastruktur ekonomi pedesaan, namun juga diperlukan guna memperbaiki infrastruktur masyarakat pedesaan itu sendiri (Subiakto, 2013).

\section{E-Commerce, Internet, dan World Wide Web}

E-commerce menyediakan fasilitas yang memudahkan melakukan transaksi dengan media teknologi digital. Peranan internet dan web menjadi aspek kunci dalam pemanfaatan e-commerce sebagai bentuk transaksi komersial yang melakukan pertukaran produk barang maupun jasa serta nilai di antara organisasi ataupun perseorangan. Bahkan transaksi nilai adalah sesuatu yang sangat urgen untuk memahami eksistensi e-commerce itu sendiri. Sebab apabila tidak terjadi transaksi nilai, sebenarnya tidak terjadi adanya perdagangan (Landon, 2008). Sementara itu, menurut Wong (2010), menyatakan bahwa pengertian e-commerce adalah merupakan transaksi (pembelian, penjualan ataupun pemasaran produk barang serta jasa melalui sistem jaringan komputer atau internet, termasuk radio dan televisi. Tantangan metode bisnis modern tidak lain untuk menjawab pentingnya memenuhi kebutuhan organisasi, merchant, maupun konsumen dalam mereduksi beban biaya yang harus dikeluarkan, sekaligus melakukan perbaikan kualitas layanan produk itu sendiri melalui kecepatan proses service delivery. Melalui metodologi tersebut mampu merubah sistem dan pola bisnis yang sifatnya tradisional menuju suatu bentuk bisnis modern yang didukung infrastruktur teknologi informasi dan komunikasi internet yang semakin diminati saat ini. Tren ini kemudian dikenal 
dengan istilah Internet Commerce yang kemudian menjadi Electronic Commerce atau ECommerce (Hartanto, 2018).

Berkembangnya pemahaman dan pemanfaatan internet (interconnection networking) yang dipahami sebagai suatu sistem komunikasi global dengan konektivitas komputer global (Purbo \& Wahyudi, 2001). Internet dengan jejaring komputer global dari segala tipe yang membentuk sistem networking dalam lingkup global menggunakan infrastruktur telekomunikasi seperti telepon, wireless, dan sebagainya. Melalui sistem internet memungkinkan masyarakat mengakses informasi serta layanan komunikasi dengan cepat. Di dalamnya terdapat berbagai macam informasi dan layanan, seperti: surat elektronik, percakapan langsung, dan halaman web yang saling berhubungan (Sutarman, 2003).

World Wide Web (WWW) atau web adalah bagian dari fasilitas yang disediakan oleh sistem internet. Web dipahami sebagai sebuah dunia maya di internet yang meliputi ribuan info tentang segala hal yang dikemas dalam bentuk dokumen hypertext. Hypertext adalah sebuah konsep dasar dari web. Dokumen hypertext merupakan suatu yang membuka peluang untuk mengeksplorasi dari satu halaman web ke halaman web yang lainnya melalui penggunaan suatu hypertext (Nugroho, 2005).

Pengertian e-commerce juga dapat dipahami sebagai aktivitas menggunakan internet dan web dalam transaksi bisnis, e-commerce secara digital memberikan kemudahan transaksi komersial antar organisasi ataupun organisasi dengan individu (Laudon dan Laudon, 2010). Sistem e-commerce menawarkan tingkat efektivitas dan efisiensi yang mampu menghemat waktu dan tempat. Kondisi demikian sangat memungkinkan karena didukung suatu sistem Wifi (sebuah teknologi dengan memanfaatkan fasilitas elektronik untuk bertukar informasi secara wireless dalam jejaring komputer global, termasuk koneksi internet berkecepatan tinggi). Fasilitas ini semakin berkembang dan meningkat melalui jasa provider (perusahaan yang menyediakan berbagai layanan yang menyangkut internet dan biasa disebut ISP/Internet Service Provider. Provider menyediakan layanan dial-up 301 JUMPA Volume 05, Nomor 02, Januari 2019 
yang menghubungkan komputer dengan internet melalui modem atau leased line) yang semakin bagus (Novitasari \& Baridwan, 2016).

\section{Konsep Desa Wisata}

Isu pengembangan kawasan pedesaan sebagai salah satu strategi mengatasi persoalan kesenjangan pembangunan desa dan kota, termasuk upaya untuk meredistribusi pendapatan (Chamber, 1995). Pengembangan desa wisata harus memperhatikan dan menampilkan kehidupan penduduk lokal dalam pola hidup dan kualitas kehidupan mereka yang mencakup lanskap pertanian, keadaan ekonomi, keadaan fisik dan sosial, warisan budaya, serta pengalaman yang unik, serta eksotisme kehidupan di lingkungan pedesaan. Dengan demikian, pemodelan desa wisata harus terus dan secara kreatif mengembangkan identitas atau ciri khas daerah (Sastrayuda, 2010).

Desa wisata adalah suatu bentuk integrasi antara atraksi, akomodasi, dan fasilitas pendukung yang disajikan dalam suatu struktur kehidupan masyarakat yang menyatu dengan tata cara dan tradisi yang berlaku. Aspek keunikan merupakan unsur utama dari pengembangan desa wisata, sebab meskipun setiap desa memiliki daya tarik, tidak serta merta dapat menjadi destinasi wisata desa. Tidak jarang terjadi imitasi atraksi yang dilakukan oleh satu desa atas objek dan daya tarik wisata di desa lain. Hal ini dalam jangka panjang dapat menimbulkan persaingan yang tidak sehat antar daerah destinasi wisata desa (Damanik, 2013).

\section{Industri Pariwisata Sebagai Bisnis Modern}

Pemahaman yang berkembang tentang pariwisata modern adalah sebuah konsep pariwisata yang menampilkan dirinya sebagai produk bisnis modern dan bersentuhan dengan sektor-sektor bisnis (Bungin, 2015), terutama berkaitan dengan sektor bisnis atau ekonomi yang digerakkan masyarakat. Dalam kontek industri pariwisata kegiatan ekonomi yang dilakukan oleh pemerintah dan nirlaba bukan termasuk bisnis pariwisata. Bisnis di bidang pariwisata dilakukan pada sektor- 
sektor ekonomi primer, tersier, dan kuartener. Pada sektor ekonomi primer, yaitu memanfaatkan sumberdaya alam secara langsung, seperti: pertanian, kehutanan, dan perikanan. Bahkan bisnis pariwisata menjadi bagian dari sektor ekonomi tersier, yaitu sebagai sektor jasa atau industri jasa. Sedangkan pada sektor kuartener bisnis pariwisata lebih pada pemanfaatan teknologi informasi.

Industri pariwisata mencakup berbagai sektor industri yang melibatkan sejumlah perusahaan secara langsung dalam pergerakkan travel product dari pelaku pasar pariwisata, seperti; prinsipal, wholesaler, organisasi pariwisata pemerintah, inbound tourism agents maupun retail agent. Beberapa sektor lain yang terkait langsung dalam aktivitas bisnis pariwisata dalam transaksi travel product kepada customers dan mempunyai peranan yang cukup penting dalam berkontribusi menyediakan fasilitas kepariwisataan adalah seperti kelompok; Tourism Government Office, Tourism Organization, Academics, dan Researchers (Yoeti, 2003).

Bisnis jasa pariwisata adalah suatu bisnis jasa yang semakin hari semakin fenomenal dengan omzetnya di seluruh dunia yang terus meningkat tajam. Banyak negara-negara yang sekarang menggantungkan pertumbuhan ekonominya dari sektor pariwisata. Benefit layanan wisata sebagai salah satu keunggulan kompetitif adalah sangat penting dilakukan. Upaya untuk memuaskan wisatawan selalu dilakukan oleh berbagai penyelenggara jasa wisata. Benefit layanan wisata adalah salah satu jalan untuk meraih kepuasan wisatawan. Seluruh elemen yang terlibat dan berkepentingan di dalam bisnis jasa wisata harus sadar dan tahu bahwa benefit layanan wisata sangatlah penting untuk dilakukan demi menciptakan kepuasan wisatawan (Bungin, 2015). Namun demikian, Nilai kearifan lokal berupa peningkatan kesadaran dan apresiasi terhadap alam serta lingkungannya, memberi nilai tambah ekonomi bagi peningkatan kesejahteraan masyarakat lokal dengan memupuk modal sosial mereka melalui kelompok-kelompok kerja (Mastika, 2018). 


\section{Metode Penelitian}

Penelitian menggunakan metode kualitatif sesuai tujuan untuk menggali informasi dari subjek penelitian yaitu penggagas yang menginisiasi adopsi sistem $e$ commerce sebagi model layanan pengunjung dan bisnis di kawasan desa wisata. Data primer diperoleh melalui wawancara mendalam dengan inisiator sekaligus sebagai Kepala Seksi Objek dan Daya Tarik Wisata Bidang Pariwisata Disparpora Kabupaten Bondowoso, data sekunder berupa dokumen RIPPDA dan dokumen lain yang mendukung. Analisis dilakukan secara deskriptif kualitatif sehingga diperoleh gambaran yang cukup untuk memahami adopsi sistem e-commerce dalam penyelenggaraan desa wisata.

\section{Pembahasan}

\section{Potensi Wisata Unggulan Kabupaten Bondowoso}

Kabupaten Bondowoso memiliki beberapa objek wisata, baik berbasis pada alam, budaya maupun buatan yang sudah dikenal di pasar wisata lokal, nasional maupun internasional. Beberapa objek yang dimaksud dirangkum dalam tabel berikut.

Tabel 1. Objek Wisata Kabupaten Bondowoso

\begin{tabular}{|c|c|c|}
\hline No. & Objek Wisata & Deskripsi \\
\hline$(1)$ & (2) & (3) \\
\hline 1. & $\begin{array}{l}\text { Gunung Ijen dan } \\
\text { pesona wisata vulcano }\end{array}$ & $\begin{array}{l}\text { Wisata Gunung Ijen dengan keunikan kalderanya berada di wilayah } \\
\text { kecamatan Klabang Bondowoso dan sebagian berada di wilayah } \\
\text { kecamatan Licin Banyuwangi. Posisi Kawah Ijen berada di ketinggian } \\
2.368 \text { meter Dpl. Kaldera kawah Ijen merupakan yang terluas di pulau } \\
\text { Jawa sekitar } 20 \mathrm{Km} \text { dengan ukuran kawah sekitar } 960 \text { meter x } 600 \\
\text { meter dan kedalaman mencapai } 200 \text { meter. Kawah Ijen berada di } \\
\text { kedalaman } 300 \text { meter dari dinding kaldera. Daya tarik lainnya adalah } \\
\text { aktivitas para penambang belerang yang berlalu lalang naik turun } \\
\text { gunung mengambil dan memikul belerang menggunakan keranjang. }\end{array}$ \\
\hline 2. & $\begin{array}{lcr}\text { Wisata } & \text { Air } & \text { Terjun } \\
\text { Blawan } & \text { dan } & \text { Gua } \\
\text { Stalagti } & & \end{array}$ & $\begin{array}{l}\text { Di desa Kalianyar kecamatan Sempol terdapat wisata Air Terjun } \\
\text { Blawan dengn jarak tempuh sekitar } 52 \mathrm{Km} \text { dari pusat kota } \\
\text { Bondowoso. Air terjun bersumber dari sungai kali pait yang } \\
\text { merupakan rembesan dari kawah ijen yang memiliki kandungan } \\
\text { kadar belerang. Di sekitar kawasan air terjun dikelilingi oleh } \\
\text { tumbuhan macadamia. Di lokasi ini dibangun fasilitas pemandian air } \\
\text { panas yang menarik untuk dinikmati oleh para pengunjung. Selain itu }\end{array}$ \\
\hline
\end{tabular}




\begin{tabular}{|c|c|c|}
\hline & & tersedia fasilitas berupa shelter dan penginapan. \\
\hline 3. & $\begin{array}{lll}\text { Wisata } & \text { Agro } & \text { Kopi } \\
\text { Kalisat } & & \end{array}$ & $\begin{array}{l}\text { Wisata berbasis perkebunan kopi merupakan kawasan perkebunan } \\
\text { PTP Nusantara XII Kalisat Jampit. Berlokasi ke arah Timur Kabupaten } \\
\text { Bondowoso dengan jarak tempuh sekitar } 57 \mathrm{Km} \text {. Luas areal } \\
\text { perkebunan mencapai } \pm 4000 \mathrm{Ha} \text { dengan letak ketinggian } 900 \text { meter } \\
\text { Dpl memberikan suasana alam yang cukup sejuk. Atraksi wisata yang } \\
\text { dapat dinikmati adalah keindahan panorama alam, keunikan proses } \\
\text { penanganan panen kopi Arabika sampai proses menjadi kopi instan } \\
\text { yang siap saji. }\end{array}$ \\
\hline 4. & $\begin{array}{l}\text { Wisata Air Terjun } \\
\text { Tancak Kembar }\end{array}$ & $\begin{array}{l}\text { Objek wisata Air Terjun Tancak Kembar yang berada di desa } \\
\text { Andongsari kecamatan Pakem Bondowoso. Ketinggian air terjun } \\
\text { mencapai } 77 \text { meter dengan iklim yang sejuk di kawasan hutan lindung } \\
\text { yang memiliki ketinggian } 900 \text { meter Dpl. Jarak menuju lokasi Air } \\
\text { terjun Tancak Kembar sekitar } 25 \mathrm{Km} \text { dari pusat kota Bondowoso. } \\
\text { Keberadaan air terjun selain untuk sarana rekreasi juga dimanfaatkan } \\
\text { untuk keperluan irigasi pertanian. Sebagian orang mempercayai } \\
\text { apabila mandi disini akan membuat awet muda. Selain itu, di kawasan } \\
\text { ini terdapat pusat penelitian kopi Arabika dan cacao seluas } 180 \mathrm{Ha} \text {. }\end{array}$ \\
\hline 5. & $\begin{array}{l}\text { Kawasan Wisata } \\
\text { Pendakian Gunung } \\
\text { Raung di Kecamatan } \\
\text { Sumber Wringin }\end{array}$ & $\begin{array}{l}\text { Wisata Gunung Raung memiliki pesona berupa view atau } \\
\text { pemandangan yang menarik, hamparan flora yang indah serta } \\
\text { berbagai jenis fauna yang hidup disana. Gunung Raung merupakan } \\
\text { pegunungan yang memiliki tipe stratovolcano berada pada ketinggian } \\
3.332 \text { meter Dpl, merupakan bagian dari deretan Pegunungan Ijen. } \\
\text { Wisata Gunung Raung terletak di wilayah desa Sumber Wringin } \\
\text { Kecamatan Sumber Wringin. }\end{array}$ \\
\hline 6. & $\begin{array}{l}\text { Wisata Panjat Tebing } \\
\text { Alam Patirana }\end{array}$ & $\begin{array}{l}\text { Atraksi wisata panjat tebing alam Patirana, memberikan nuasa yang } \\
\text { cukup menantang bagi pengunjung yang menyukai olah raga panjat } \\
\text { tebing. Ketinggian tebing mencapai } 45-75 \text { meter serta kemiringan } \\
\text { mencapai } 90 \text { derajat. Wisata panjat tebing alam Patirana berlokasi di } \\
\text { desa Patirana kecamatan Grujugan dengan jarak tempuh sekitar } 7 \mathrm{Km} \\
\text { dari Kota Bondowoso. }\end{array}$ \\
\hline 7. & $\begin{array}{l}\text { Kawasan Wisata } \\
\text { Pemandian Tasnan di } \\
\text { Kecamatan Grujugan }\end{array}$ & $\begin{array}{l}\text { Wisata pemandian yang cukup menarik adalah Taman Pemandian } \\
\text { Tasnan, memiliki keindahan dan kenyamanan dalam beraktivitas } \\
\text { wisata. Disini dilengkapi dengan fasilitas berupa shelter, ruang ganti, } \\
\text { mushola,panggung hiburan serta taman tempat beristirahat. } \\
\text { Pemandian Tasnan terletak di desa Taman Kecamatan Grujugan } \\
\text { tepatnya } \pm 8 \mathrm{Km} \text { dari Kota Bondowoso. }\end{array}$ \\
\hline$(1)$ & $(2)$ & (3) \\
\hline 8. & $\begin{array}{l}\text { Kawasan Wisata } \\
\text { Sejarah Sarkopage }\end{array}$ & $\begin{array}{l}\text { Kabupaten Bondowoso juga memiliki objek wisata sejarah berupa } \\
\text { situs Sarkopage yaitu salah satu dari situs megalitikum yang lebih } \\
\text { dikenal dengan nama keranda yang dibuat dari batu atau sejenis batu } \\
\text { cadas. Berbentuk lesung atau palung, tetapi memiliki penutup. } \\
\text { Fungsinya sama dengan kuburan batu/dolmen. Sarkopage dapat } \\
\text { ditemui di beberapa desa, seperti Desa Glinseran - Kecamatan } \\
\text { Wringin. Tepatnya } \pm 19 \mathrm{Km} \text { ke arah Barat Kota Bondowoso. Adapun } \\
\text { jarak Bondowoso menuju Wringin adalah } 17 \mathrm{Km} \text {, lalu dari Wringin ke } \\
\text { Lokasi Sakopage adalah } 2 \mathrm{Km} \text {. }\end{array}$ \\
\hline 9. & $\begin{array}{l}\text { Wisata Budaya } \\
\text { Upacara Adat }\end{array}$ & $\begin{array}{l}\text { Wisata budaya yang ada di kabupaten Bondowoso berupa seni tradisi } \\
\text { Singo Wulung yang lahir di Desa Belimbing, kecamatan Klabang, } \\
\text { Bondowoso. Tradisi pentas Singo Wulung biasa digelar setiap tahun }\end{array}$ \\
\hline
\end{tabular}




\begin{tabular}{|l|l|l|}
\hline & & $\begin{array}{l}\text { menjelang bulan Ramadhan di Desa Belimbing. Kegiatan ini } \\
\text { merupakan tradisi bagi warga Desa Belimbing dengan menggelar } \\
\text { upacara bersih desa pada Sya'ban menjelang bulan Ramadhan. }\end{array}$ \\
\hline 10. & $\begin{array}{l}\text { Wisata Kerajinan } \\
\text { Kuningan Cindogo }\end{array}$ & $\begin{array}{l}\text { Salah satu objek wisata yang menarik adalah berupa sentra kerajinan } \\
\text { kuningan. Tempat wisata kerajinan kuningan Cindogo Bondowoso } \\
\text { terletak di desa Cindogo, kecamatan Tapen, merupakan kerajinan } \\
\text { kuningan khas Bondowoso yang mengkilat dan warnanya bertahan } \\
\text { lebih lama. }\end{array}$ \\
\hline 11. & $\begin{array}{l}\text { Objek Wisata Arung } \\
\text { Jeram Bosamba }\end{array}$ & $\begin{array}{l}\text { Atraksi wisata alam berupa arung jeram merupakan salah satu pilihan } \\
\text { masyarakat dalam menikmati keindahan alam menyelusuri alur dan } \\
\text { arus sungai berupa arung jeram. Obyek wisata yang tengah } \\
\text { dikembangkan oleh Pemerintah Kabupaten Bondowoso untuk } \\
\text { menyajikan wisata olah raga yang disukai para pecinta olah raga } \\
\text { arung jeram dari daerah lain, juga tidak ketinggalan untuk } \\
\text { menikmatinya. Akses menuju tempat ini sangat mudah karena dapat } \\
\text { di lewati oleh transportasi umum. }\end{array}$ \\
\hline
\end{tabular}

Sumber: Data RIPPDA Kabupaten Bondowoso, Diolah (2018)

\section{Alur Pembentukan, Pengelolaan dan pengembangan Desa Wisata Di Kabupaten Bondowoso}

Dalam pembentukkan desa wisata di wilayahnya, pemerintah kabupaten Bondowoso melalui kerja terpadu antar SKPD terkait agar berbagai aspek fisik dan non fisik dapat berjalan sejajar menuju terwujudnya desa wisata yang diharapkan. Alur pembentukkan desa wisata meliputi beberapa tahap dan proses, sebagai berikut.

1. Melakukan pemetaan atas potensi-potensi pariwisata dan ekonomi kreatif yang berbasis pada pemberdayaan dan potensi desa melalui musrenbang tingkat desa, kecamatan dan tingkat kabupaten.

2. Menetapkan regulasi dan kebijakan tentang desa wisata dalam regulasi peraturan daerah baik Perda RTRW kabupaten Bondowoso, Rencana Induk Pembangunan Pariwisata Daerah Bondowoso, Perda retribusi sektor pariwisata, Peraturan Desa (Perdes) dan lain sebagainya.

3. Memasukkan tema Pariwisata dalam RPJMD kabupaten Bondowoso untuk kemudian diimplementasikan dalam program dan kegiatan organisasi perangkat daerah (OPD) sesuai dengan tugas dan fungsi masing-masing.

4. Memasukkan tema pariwisata dalam RPJMdes masing-masing desa wisata sebagai perwujudan keseriusan dan komitmen pembangunan desa wisata untuk 
kemudian diwujudkan dalam RKPdes sebagai dasar penggunaan Dana Desa (DD) dan ADD (Alokasi Dana Desa).

5. Membentuk Kelompok sadar wisata yang resmi dan berbadan hukum di setiap Desa Wisata yang ada di kabupaten Bondowoso sebagai operator utama kegiatan kepariwisataan di desa wisata.

6. Memberikan dukungan operasional terhadap desa wisata melalui peran serta BUMDES di masing-masing desa dengan pembentukan unit usaha pariwisata di BUMDES sebagaimana dimaksud.

7. Melakukan peningkatan kualitas kelembagaan dan kemampuan SDM yang sadar wisata, sesuai dengan potensi keunggulan masing-masing desa wisata melalui konsep kerja Bondowoso In-Corporate (Pemerataan dan Pembagian Tugas Program Kegiatan Pembangunan bersama-sama sesuai dengan tugas dan fungsi OPD Pemerintah Kabupaten Bondowoso).

8. Pemanfaatan teknologi Informasi dan sistem pemasaran promosi pariwisata baik itu berupa aplikasi layanan informasi wisata, website, facebook, Instagram dan media sosial lainnya yang dioperasikan secara aktif dan update oleh Pokdarwis (Pokja Humas dan IT).

9. Melakukan kesepakatan dan kesepahaman Bundling Promotion Tourist Sister Village antar desa wisata di kabupaten Bondowoso yang dikoordinasi oleh Disparpora Kabupaten Bondowoso dan Pokdarwis Kabupaten Bondowoso.

\section{Pemanfaatan Teknologi Informasi dalam Pemasaran Pariwisata (IT-Based Marketing)}

Besarnya manfaat mengadopsi aplikasi teknologi informasi dan komunikasi dalam bidang pariwisata, sebagaimana optimisme yang diungkapkan Menteri Pariwisata, bahwa pariwisata akan mampu memutus kemiskinan, pengangguran, dan kesenjangan dengan cepat dan tepat, dikatakan bahwa pemerintah optimistis pariwisata menjadi core economy negara ini ke depan. Lebih lanjut dikatakan ecommerce dan pariwisata menjadi unggulan 2018 (www.ngopibareng.id, 2018). 
Kebijakan pemanfaatan Teknologi Informasi yang dituangkan ke dalam RIPPDA Kabupaten Bondowoso sudah tepat. Beberapa pertimbangan yang melandasi pemikiran pemanfaatan teknologi informasi dalam pemasaaran pariwisata, sebagai berikut.

a) Rendahnya kinerja pemasaran dan besarnya pemborosan anggaran promosi yang terjadi selama ini telah banyak diakibatkan oleh tumpang tindihnya kegiatan serta tidak memadainya sistem informasi yang dibutuhkan.

b) Efektivitas dan efisiensi pemasaran;

c) Promosi merupakan salah satu proses penting dalam pemasaran yang akan menghubungkan antara persediaan dan permintaan;

d) Diperlukan pemanfaatan kemajuan teknologi informasi pada pemasaran pariwisata, baik internasional maupun daerah.

e) Penggunaan teknologi informasi untuk menunjang pemasaran dan sektor industri kecil dan menengah dibidang pariwisata.

f) Diperlukan organisasi pemasaran (lini distribusi) dengan melibatkan stakeholder terkait, khususnya di daerah.

g) Penggunaan internet sebagai salah satu media keterpaduan jaringan pemasaran.

\section{Adopsi dan Aplikasi E-Commerce dalam Pengembangan UMKM dan UKM Pariwisata Kabupaten Bondowoso}

Gagasan mengadopsi sistem e-commers di Bondowoso telah dibuat aplikasi dalam media seluler yang mudah diakses masyarakat yang membutuhkan layanan dengan menu layanan sebagaimana dalam gambar berikut ini. Otw Boss merupakan aplikasi yang memberikan layanan ojek dan tiket wisata di bondowoso secara online yang bisa di akses oleh semua orang dan wisatawan. Aplikasi ini salah satunya bertujuan untuk menyediakan akses layanan cepat bagi wisatawan menuju berbagai destinasi wisata yang ada di kabupaten Bondowoso dengan lebih cepat, aman, tepat, dan kreatif (Cantik). 


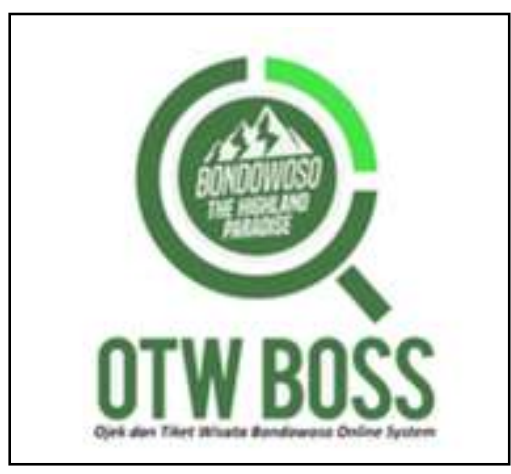

Gambar 1. Brand Otw Boss Sumber : apkgk.com (2018)

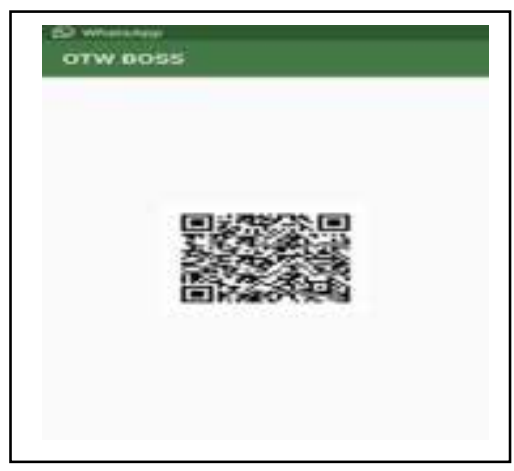

Gambar 2. Barcode Otw Boss

Sumber : apkgk.com (2018)

Terkait dengan gagasan adopsi teknologi informasi dalam aktivitas ekonomis pariwisata dengan mengadopsi sistem e-commerce, diungkapkan oleh Kepala Seksi Objek dan Daya Tarik Wisata Bidang Pariwisata Disparpora Kabupaten Bondowoso, sebagai berikut.

“...saya berinisiatif mengaplikasi ala Gojek atau Grab dan mengajak temen-temen lulusan Teknik UNEJ, Poltek Jember, dan Teknik UNMUH Jember. Konsep saya bikin berbeda dengan Gojek, yaitu lebih mengarah kepada UMKM dan UKM, mak emak di desa kini bisa memanfaatkan model sistem e-commerce, tidak perlu lagi buka warung, kita punya basis data digital transasksi yang riil datanya dan riil uangnya." (Wawancara, September 2018).

Ride sharing istilah yang makin popular belakangan ini melekat pada profesi menjadi driver ojek atau taksi online yang kian diminati masyarakat. Bekerja sebagai driver ojek dan taksi online terus dicari pencari kerja. Terkait dengan minat masyarakat menjadi driver transportasi online, dikatakan oleh Kepala Seksi Objek dan Daya Tarik Wisata Bidang Pariwisata Disparpora Kabupaten Bondowoso, sebagai berikut.

“...saya sebenarnya terinspirasi ketika berpikir tentangnya hengkangnya Grab dari Indonesia, saya pikir Uber perusahaan besar milik Silicon Valey bisa tersingkir oleh Gojek Indonesia, kenapa kita orang Bondowoso tidak membuat saja ojek online. Gagasan ini saya sampaikan kepada temen-temen ketika Festival Muharom, kebetulan saya sebagai ketua paguyuban PKL yang keanggotaan sampai saat ini mencapai 34 orang rata-rata usia 32 tahun." (Wawancara, September 2018). 
Jenis aplikasi yang sudah berjalan adalah aplikasi untuk ride sharing dan sejenis Go-Pay dalam sistem Go-Jek. Hal tersebut merupakan aplikasi dalam transaksi e-commerce, order konsumen disampaikan secara online ke pedagang, selanjutnya bilaorder sudah masuk ke pedagang dan diverifikasi oleh pedagang, kemudian pembayaran dilakukan oleh pelanggan juga secara online melalui server pembayaran. Agar transaksi online terjaga keamanannya, startup menjadi perantara akan bekerjasama dengan sejumlah lembaga keuangan perbankan dalam memfasilitasi e-payment secara aman, cepat dan praktis. Terkait dengan model sistem ride sharing dan e-payment, Kepala Seksi Objek dan Daya Tarik Wisata Bidang Pariwisata Disparpora Kabupaten Bondowoso, menyatakan sebagai berikut.

“...aplikasi transaksi ojek online berbasis digital yang kemudian saya beri nama "TERATER" (bahasa Madura) di play store sudah ada. Pengguna TERATER selama enam bulan sudah ada 6.000 pengguna. untuk aplikasi pembayaran, saya juga membuat seperti halnya emoney dan beri nama "E-Bajer" (bahasa Madura). Ketertarikan masyarakat untuk mengikuti ojek online "TERATER" tersalurkan karena kalau mereka ikut Gojek mereka harus membayar, sementara dalam ojek online TERATER dibebaskan dari biaya dan tidak dipungut prosentase. Namun hanya dikenakan kepada kurir biaya angkut dan aplikasi sudah disediakan. Bagi bisnis yang di desa wisata, misalnya kuliner dan lainnya, mereka memperoleh $20 \%$. Karyawan yang terlibat dalam pengelolaan aplikasi digital tercatat 34 orang yang terdiri atas kurir sebanyak 25 orang dan programmer sejumlah 9 orang." (Wawancara, September 2018).

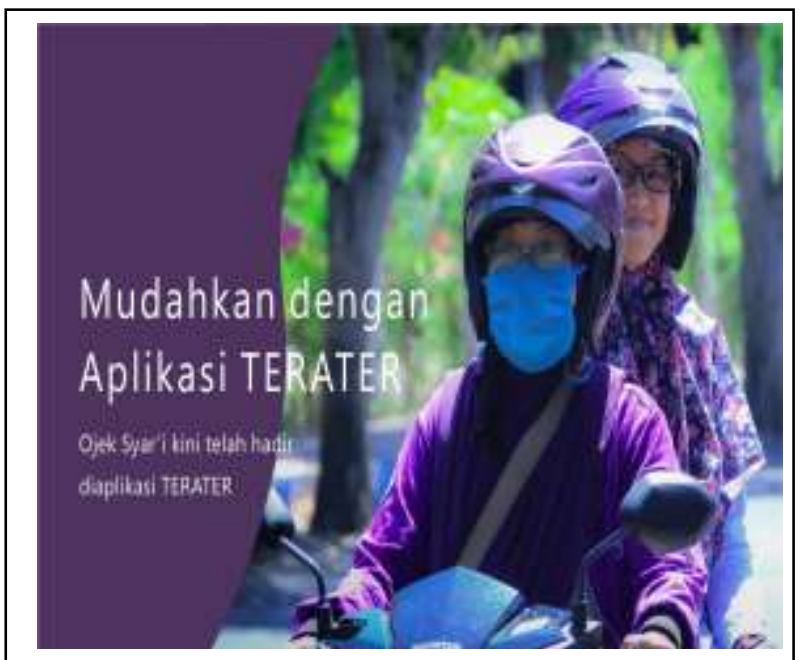

Gambar 3. Profil Ojek Online TERATER Sumber : teaterinstagram (2018)

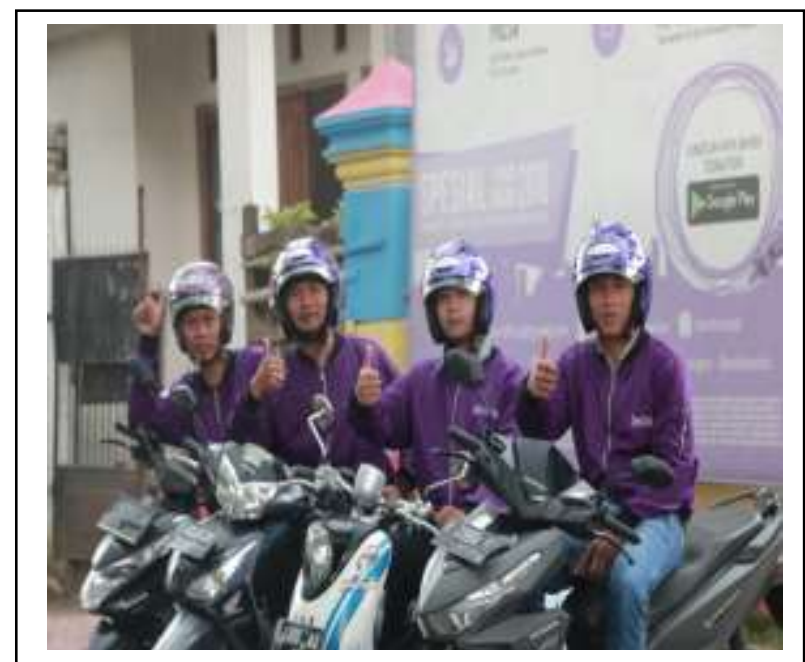

Gambar 4. TERATER siap melayani pesanan Sumber : teaterinstagram (2018) 
Untuk memberi edukasi dan motivasi kepada penduduk lokal dalam mengadopsi bisnis modern, yang mengedepankan kualitas layanan, mutu produk, kecepatan dan kenyamanan. Kepala Seksi Objek dan Daya Tarik Wisata Bidang Pariwisata Disparpora Kabupaten Bondowoso, mengungkapkan sebagai berikut.

“...saya menekankan, kalau membuat produk, dan jika tidak mampu, saya akan bantu mendisain produk karena saya punya tim disain. Demikian pula, kalau membuat produk harus bagus, menarik, dan laku. Saya tidak menyiapkan museum untuk produk-produk tidak laku. Nah mudah-mudahan dengan cara ini dapat memotivasi masyarakat untuk giat, kreatif dan inovatif dalam meningkatkan produktivitas usaha pedesaan." (Wawancara, September 2018).

Terobosan aplikasi Ride Sharing dengan TERATER dan E-Payment dengan EBajer oleh komonitas dan inisiator staf Disparpora Kabupaten Bondowoso sejalan dengan tujuan untuk membangun dan mengembangkan model pariwisata modern melalui adopsi sistem e-commerce. Dengan demikian telah diimplementasikan konsep pariwisata yang mendefinisikan dirinya sebagai produk bisnis modern dan bersentuhan dengan sektor-sektor bisnis, meliputi bisnis di sektor-sektor ekonomi primer, tersier, dan kuartener.

Pemanfaatan teknologi Informasi dan sistem e-commerce dalam sistem pemasaran promosi pariwisata maupun bisnis di sektor UMKM pariwisata pedesaan di kabupaten Bondowoso telah mampu direalisasikan dengan melibatkan potensi SDM yang memahami teknologi informasi, yaitu para sarjana teknik elektronik dan mampu sebagai programmer digitalisasi dan tim disain. Inisiator telah mampu mengonstruksi komunitas berbasis e-commerce yang memberikan dampak positif dibidang transaksi digital. Manfaat sangat dirasakan baik pada aspek ride sharing, pembayaran elektronik (e-payment), dan efektivitas serta efisiensi bisnis home industry, kuliner dan lainya yang ada di pedesaan.

Keinginan pemerintah untuk mewujudkan masyarakat modern yang tidak tertinggal dari lingkungan globalisasi, telah mendapat rintisan dari daerah. Kebijakan pemerintah dalam merealisasikan komitmen azas adil dan merata akan 
layanan telekomunikasi melalui program-program Universal Service Obligation (USO), sebagai sarana memperkenalkan bidang information and communication technology (ICT) kepada masyarakat. Menjadikan adopsi dan aplikasi E-Commerce dalam pengembangan UMKM pariwisata kabupaten Bondowoso adalah wujud nyata keberhasilan sosialiasi pemanfaatan teknologi informasi oleh pemerintah yang direspon secara aktif dan kreatif oleh masyarakat di kabupaten Bondowoso.

Metodologi bisnis modern sudah dirasakan masyarakat dalam menekan biaya-biaya yang harus dikeluarkan dengan diikuti perbaikan kualitas barang dan jasa, serta kecepatan service delivery. Metodologi tersebut mengubah pola bisnis tradisional menjadi pola bisnis modern dengan pemanfaatan internet dan konsep sistem Electronic Commerce atau E-Commerce.

Benefit layanan wisata adalah salah satu jalan untuk meraih kepuasan wisatawan. Seluruh elemen yang terlibat dan berkepentingan di dalam bisnis jasa wisata semakin menyadari dan tahu bahwa benefit layanan wisata sangatlah penting untuk dilakukan demi menciptakan kepuasan wisatawan. Isu pengembangan kawasan pedesaan sebagai salah satu strategi mengatasi persoalan kesenjangan pembangunan desa dan kota, termasuk upaya untuk meredistribusi pendapatan dapat terealisasi dengan pemanfaatan dan pengembangan sistem e-commerce dalam bisnis pariwisata. Dengan demikian, apa yang dikatakan bahwa sektor pariwisata akan mampu memutus kemiskinan, pengangguran, dan kesenjangan dengan cepat dan tepat, betul-betul menjadi optimisme yang realistik. bahwa pemerintah optimistis pariwisata menjadi core economy negara ini ke depan. Sebab, meningkatkan produktivitas perekonomian di daerah, menunjukkan bahwa keberadaan teknologi informasi dan komunikasi merupakan bentuk pemberdayaan individual (Individual Empowering) sebagaimana sudah lama dinyatakan oleh D'Allesandro \& Dosa (2001). 


\section{Simpulan dan Saran}

Bidang Pariwisata Kabupaten Bondowoso melalui Seksi Objek dan Daya Tarik Wisata telah berhasil menginisiasi komunitas UMKM PKL dan kalangan intelektual muda yang memiliki kompetensi teknologi digital merancang aplikasi Ride Sharing TERATER dan sistem E-Payment yang diberi nama E-bajer. Komunitas ini memiliki 25 karyawan dan 9 tenaga pemrograman termasuk sebagai tim disain produk. Pengguna ojek online TERATER sudah mencapai 6.000 orang. Keberadaan sistem digital transaction ini sangat disambut baik oleh warga desa yang ada di kawasan desa wisata kabupaten Bondowoso. Para ibu di pedesaan yang memiliki usaha home industry tidak perlu repot menyiapkan tempat bagi konsumen yang memesan produk, cukup pemesanan melalui online, delivery order segera dapat dipenuhi dan dikirim melalui kurir TERATER. Demikian juga dengan pembayaran sudah berbasis online melalui sistem E-Bajer. Berdasarkan hasil penelitian menunjukan bahwa adopsi E-Commerce sebagai sistem pelayanan pengunjung di lingkungan desa wisata di kabupaten Bondowoso telah berhasil.

\section{Daftar Pustaka}

Bungin, B. 2015. Komunikasi Pariwisata, Tourism Communication, Pemasaran dan Brand Destinasi, Jakarta: Prenadamedia Group.

Chambers, R. 1995. Rural Development: Putting the last first, England: Longman Group Limited.

Damanik, J. 2013. Pariwisata Indonesia: Antara Peluang dan Tantangan, Yogyakarta: Pustaka Pelajar (Anggota IKAPI).

D'Allesandro D. Dosa, N .2001. Empowering children and families with information technology. Archive of Peadriatric \& Adolescent Medicine 155(10): 1131-6.

Hartanto, R. 2018. E-Commerce. Transkrip Presentasi, SlidePlayer.info Inc. https://slideplayer.info/slide/ 1972952/

Jony Wong, J. 2010. Internet Marketing for Beginners, Jakarta: PT Elex Media Komputindo.

Katz JR Rice. Aspden, P. 2001. The Internet 1995-2000: Access, civic involvement and social Interaction. American Behavioural Scientist 45(3): 405-19. 
Laudon, K.C., Laudon, J.P. 2010. Manajemen Information System: Managing the Digital Firm. New Jersey: Prentice-Hall

Mastika, I K. 2018. Pengembangan Ekowisata Berwawasan Kearifan Lokal di Wilayah eks. Karesidenan Besuki, Jawa Timur, JUMPA Volume 4 Nomor 2, Januari 2018, Jurnal Magister Pariwisata, Universitas Udayana.

Muntu, A.W., Wiranatha, A.S., Arida, N.S. 2018, Analisis Partisipasi Komunitas Lokal Dalam Pengembangan Daya Tarik Wisata Kota Tua Jakarta, JUMPA Volume 4 Nomor 2, Januari 2018, Jurnal Magister Pariwisata, Universitas Udayana.

Novitasari \& Baridwan. (2016). Pengaruh Kepercayaan, Persepsi Resiko, Persepsi Manfaat, dan Persepsi Kontrol Perilaku Terhadap Niat Penggunaan Sistem E-Commerce, Malang: Jurnal Ilmiah Mahasiswa FEB, Vol. 3 No. 1.

Nugroho, B., 2005, Membuat aplikasi penjualan dengan PHP - MySQL, Yogyakarta : Andi Offset.

Purbo O. W., Wahyudi A. A., 2001, Mengenal E-commerce, Jakarta : PT Elex Media Komputindo.

Pakpahan, R. 2018. Implementasi Prinsip Pariwisata Berbasis Komunitas di Desa Wisata Nglinggo, JUMPA Volume 05, Nomor 01, Juli 2018, Jurnal Magister Pariwisata, Universitas Udayana.

Sastrayuda, G. S. 2010. Konsep Pengembangan Desa Wisata, Hand Out Mata Kuliah Concept Resort and Leisure, Strategi Pengembangan dan Pengelolaan Resort and Leisure. file:///C:/Users/TOSHIBA-PC/Documents/Branding /Reading\%20Course/

Subiakto, H. 2013. Internet untuk pedesaan dan pemanfaatannya bagi masyarakat. Masyarakat, Kebudayaan dan Politik, Vol. 26, No. 4.

Sutarman., 2003, Membangun aplikasi web dengan PHP dan MySQL, Yogyakarta : Graha ilmu.

Yoeti, O.A. 2003. Tours and Travel Marketing. Jakarta: Pradnya Paramita.

https://www.ngopibareng.id/timeline/e-commerce-dan-pariwisata-jadi-unggulan2018-1753986 06 Jan 2018 


\section{Profil Penulis}

Dr. I Ketut Mastika, M.M adalah pengajar tetap pada Program Studi Ilmu Administrasi Bisnis FISIP Universitas Jember. Bidang keahlian beliau adalah Branding Ekowisata.

Dr Sasongko,MSi adalah pengajar tetap pada Program Studi Ilmu Administrasi Bisnis FISIP Universitas Jember. Bidang keahlian beliau adalah Manajemen Sumber Daya Manusia.

Drs. Didik Eko Julianto,MAB adalah dosen tetap pada Program Studi Ilmu Administrasi Bisnis FISIP Universitas Jember. Bidang keahlian beliau adalah Manajemen Pemasaran

Drs. Rudy Eko Pramono, M.Si adalah pengajar tetap pada Program Studi Ilmu Administrasi Bisnis FISIP Universitas Jember. Bidang keahlian beliau adalah UMKM

Dra. Sri Wahyuni, M.Si adalah pengajar tetap pada Program Studi Ilmu Administrasi Bisnis FISIP Universitas Jember. Bidang keahlian beliau adalah Perilaku Organisasi. 